\title{
Differentiation of nestin-positive cells derived from bone marrow into pancreatic endocrine and ductal cells in vitro
}

\author{
Anna Milanesi ${ }^{1}$, Jang-Won Lee ${ }^{2}$, Qijin $\mathrm{Xu}^{2}{ }^{2}$, Laura Perin ${ }^{3}$ and John $\mathrm{S} \mathbf{Y u}^{2}$ \\ ${ }^{1}$ Division of Endocrinology and ${ }^{2}$ Department of Neurosurgery, Maxime Dunitz Neurosurgical Institute, Cedars-Sinai Medical Center, 8631 West $3 r d$ Street, \\ Suite 800 East, Los Angeles, California 90048, USA \\ ${ }^{3}$ Department of Urology, Children's Hospital Los Angeles, University of Southern California, Los Angeles, California 90027, USA \\ (Correspondence should be addressed to J S Yu; Email: john.yu@cshs.org)
}

\begin{abstract}
Promising results of pancreatic islet transplantation to treat type 1 diabetes mellitus, combined with severe shortage of donor pancreata, have spurred efforts to generate pancreatic islet-like cells and insulin-producing $\beta$-cells from various progenitor populations. In this study, we show for the first time that multipotent nestin-positive stem cells selected from rat bone marrow can be differentiated into pancreatic ductal and insulin-producing $\beta$-cells in vitro. We report an effective multistep protocol in a serum-free system, which could efficiently induce $\beta$-cell differentiation from multipotent nestin-positive bone marrow stem cells. To enhance the induction and differentiation toward pancreatic lineage we used trichostatin $\mathrm{A}$, an important regulator of chromatin remodeling, and 5-aza $2^{\prime}$ deoxycytidine, an inhibitor of DNA
\end{abstract}

methylase. All-trans retinoic acid was then utilized to promote pancreatic differentiation. We sequentially induced important transcription factor genes, such as $P d x 1, N g n 3$, and Pax6, following the in vivo development timeline of the pancreas in rats. Furthermore, in the final stage with the presence of nicotinamide, the induced cells expressed islet and ductal specific markers. The differentiated cells not only expressed insulin and glucose transporter 2, but also displayed a glucoseresponsive secretion of the hormone. Our results delineate a new model system to study islet neogenesis and possible pharmaceutical targets. Nestin-positive bone marrow stem cells may be therapeutically relevant for $\beta$-cell replacement in type 1 diabetes.

Journal of Endocrinology (2011) 209, 193-201

\section{Introduction}

Understanding the mechanisms of $\beta$-cell homeostasis and regenerative repair is crucial not only to provide new insights on diabetes mellitus pathogenesis, but also to address potential therapeutic application. Islet cell transplantation may be a promising approach for cell replacement in type 1 diabetes. However, islet availability for allogeneic transplantation is limited (Lakey et al. 2006, Shapiro et al. 2006). In addition, understanding the origin of new $\beta$-cells in adults may help devise ways of slowing down progression of type 2 diabetes.

The mechanisms by which $\beta$-cell mass is maintained in adulthood are not yet known and the origin of new $\beta$-cells in adults is the focus of intensive research. The literature is replete with studies trying to characterize a putative pancreatic progenitor cell in and outside the pancreas that could explain $\beta$-cell neogenesis in adult life. Should such a cell be identified, it could be used as a potential source of cell therapy. It has been demonstrated that replacement of $\beta$-cells in the post-natal period precedes both the proliferation of existing mature $\beta$-cells (Dor et al. 2004), and the neogenesis of new $\beta$-cells from progenitor epithelial cells. It has been proposed that these adult pancreatic progenitor cells reside in the epithelium of the pancreatic duct (Bouwens \& Kloppel 1996, Bonner-Weir 2000, 2001), inside islets (Zulewski et al. 2001) and in the bone marrow (Ianus et al. 2003).

Nestin is an intermediate filament protein known as a marker of neuroepithelial stem cells, because it is expressed transiently in early developmental stages as well as in the process of tissue regeneration in various organs (Lendahl et al. 1990, Morshead et al. 1994, Matsuoka et al. 2002). Immunohistochemical studies showed the presence of nestinpositive cells within the islet, the acinar and the ductal compartment of the prenatal and newborn pancreas (Hunziker \& Stein 2000, Zulewski et al. 2001, Kim et al. 2004, Yashpal et al. 2004). The developmental progression and the change in nestin immunoreactivity throughout the fetal pancreas to postnatal transition suggest that nestinpositive cells are probably a population of progenitor cells within the pancreas (Yashpal et al. 2004). Moreover, Zulewski et al. (2001) described the existence of a distinct population of cells within islets and in a focal region of pancreatic ducts and exocrine pancreas expressing nestin that can proliferate and differentiate into pancreatic, exocrine, ductal and endocrine cells in culture. A recent publication showed that suppression of nestin expression in embryonic stem cells by gene silencing 
reduced endodermal and pancreatic transcription factor expression (Kim et al. 2010). During embryonic development, neural and islet cells express a subset of markers in common. Developing islet cells express several neuronalspecific markers, such as synaptophysins, nerve-specific enolasis (Alpert et al. 1988), and transcription factor genes such as Isl-1, Pax6, Pax 4, $\beta 2$ /NeuroD, and IDX1 (Reynolds \& Weiss 1996, Madsen et al. 1997, Sander \& German 1997).

Therefore, these data suggest that nestin could be a common marker of a precursor stem cell for both neuronal and islet cell types. We previously demonstrated that a subpopulation of nestin-expressing cells, isolated from bone marrow is able to generate cellular spheres similar to neurospheres derived from brain neural stem cells. These cells from bone marrow could differentiate into all three neural phenotypes (neurons, astrocytes, and oligodendrocytes) in vitro and in vivo (Kabos et al. 2002, Zeng et al. 2007). Recent studies showed that bone marrow-derived stem cells could reverse the hyperglycemic phenotype in a diabetic animal model but the mechanism behind the rescue or regeneration of pancreatic islets is still debated (Hasegawa et al. 2007, Xu et al. 2007, Gao et al. 2008, Zhao et al. 2008). Based on these we hypothesized that nestin-positive cells from bone marrow (bone marrow-derived stem cells, n-BMSCs) could be differentiated to pancreatic cell phenotypes by serial epigenetic manipulations.

We reported a newly developed and effective method that could successfully induce directly n-BMSC to differentiate into pancreatic cell lineage. In the first step (chromatin remodeling) we used an inhibitor of DNA methylase, and 5-aza $2^{\prime}$ deoxycytidine (5-AZA), which has been shown to be important in differentiation process, including pancreatic differentiation (Lefebvre et al. 2009), and a histone deacetylases (HDACs) inhibitor, trichostatin A (TSA), to loosen chromatin structure and permit differentiation through epigenetic manipulations (Chang et al. 2004). In the second step, retinoic acid (RA) was used to promote pancreatic differentiation, consistent with the previous observation that RA is required for early pancreas development in human and mice (Ostrom et al. 2008). In the last step, we used nicotinamide, which has been reported to induce differentiation/maturation of precursor/stem cells toward a $\beta$-cell phenotype and enhance insulin biosynthesis (Ye et al. 2006).

This system can provide a novel source for generating $\beta$-cells and can be utilized as a model to study the mechanism of islet neogenesis, which will facilitate identifying pharmaceutical targets to treat insulin-dependent diabetes.

\section{Materials and Methods}

\section{Cell isolation and culture}

Adult Fisher rats were purchased from Charles River Laboratories (Wilmington, MA, USA). They were killed by $\mathrm{CO}_{2}$ asphyxiation according to an approved protocol by the

Institutional Animal Care and Use Committee at Cedars Sinai Medical Center. Whole bone marrow was harvested from the femurs as previously published (Talmor et al. 1998). Briefly, the femurs were isolated from the muscle tissues and both ends of the bones were cut. The marrow was flushed and the tissue was passed through a mesh to remove small pieces of debris. After washing, nestin-positive spheres were obtained as described previously by our group (Kabos et al. 2002). Cells were plated at a density of $1 \times 10^{6}$ cells/well in poly-D lysinecoated 24-well plates (BD Biosciences, San Jose, CA, USA) in serum-free DMEM/F12 medium (Invitrogen), supplemented with $20 \%$ B27 (Invitrogen), $20 \mathrm{ng} / \mathrm{ml}$ of fibroblast growth factor (bFGF, Peprotech, Rocky Hill, NJ, USA), $20 \mathrm{ng} / \mathrm{ml}$ of epidermal growth factor (EGF, Peprotech), penicillin $(100 \mathrm{U} / \mathrm{ml})$ and streptomycin $(100 \mu \mathrm{g} / \mathrm{ml})$. Medium was changed every 2 days. Cells were maintained at $37^{\circ} \mathrm{C}$ in a humidified atmosphere containing $5 \% \mathrm{CO}_{2}$. Portions of cells from sphere forming were dissociated to single cells, frozen down (10\% dimethylsulfoxide and 40\% fetal bovine serum) by cryotank in $-80{ }^{\circ} \mathrm{C}$ for overnight and put into the liquid nitrogen (LN2) tank for maintenance of cell populations.

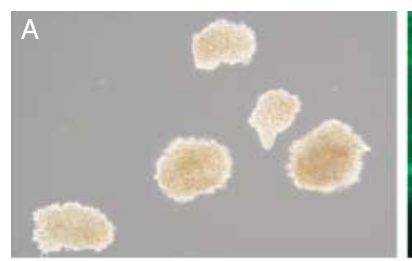

C

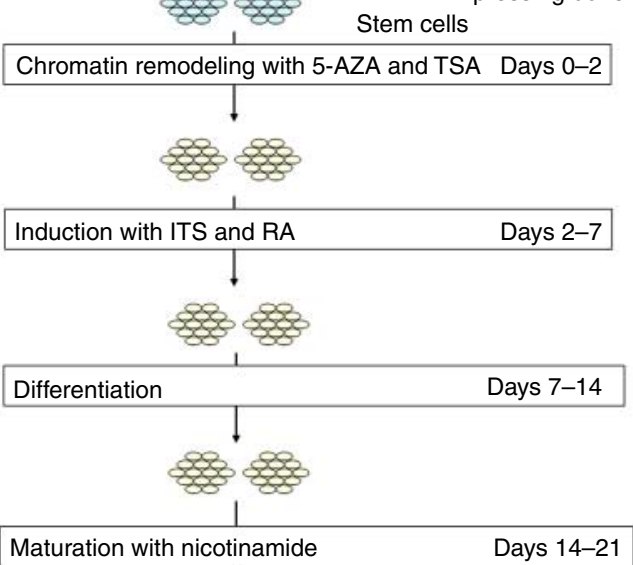

Maturation with nicotinamide $\downarrow$

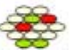

Pancreatic endocrine and ductal phenotype

Figure 1 Differentiation steps of multipotent nestin-positive stem cell isolated from rat bone marrow (n-BMSC). Multipotent rat bone marrow stem cells formed neurospheres in vitro (A) (magnification $\times 10$ ) and stained positive for nestin (B) (magnification $\times 20$ ). (C) Schematic representation of multistep differentiation protocol of $\mathrm{n}$-BMSC to pancreatic lineage (endocrine and ductal phenotype): chromatin remodeling with 5-AZA and TSA (step 1), induction with ITS and RA (step 2), differentiation (step 3), and maturation with nicotinamide (step 4). Full colour version of this figure available via http://dx.doi.org/10.1530/JOE-10-0344. 
For control experiment rat bone marrow mesenchymal stem cells (MSCs-BM) were cultured on $\alpha$-MEN medium (Invitrogen) supplemented with 10\% FCS (Invitrogen). Briefly, the cells collected from bone marrow (as described earlier) were plated into tissue culture-treated dishes of $100 \mathrm{~mm}$ in diameter at $37^{\circ} \mathrm{C}$ in a humidified atmosphere containing $5 \% \mathrm{CO}_{2}$. After $24 \mathrm{~h}$, floating cells were washed out and only adherent cells were maintained in the culture with medium changed every 3 days. Cells which reached $80-90 \%$ confluency in $100 \mathrm{~mm}$ dish were passaged to $1: 4$ and cultured in the same medium.

\section{Cell culture and differentiation}

We have previously described the successful selection, from rat whole bone marrow, of multipotent stem cells expressing nestin (n-BMSC) and forming a spheroid structure with phenotypic characteristics and a genetic signature typical of neuropheres (Kabos et al. 2002).

We established a complex differentiation protocol comprised of four basic steps (Fig. 1). Control experiments were conducted in parallel using rat MSCs-BM. In the first step (chromatin remodeling), nestin-positive spheres were plated at a concentration of about 100 spheres $/ \mathrm{ml}$ in each well of 6-well culture plate (Corning, Corning, NY, USA), in a basal medium containing KO-DMEM and main components: $0.1 \mathrm{mM} \beta$-mercaptoethanol, $2 \mathrm{nM}$ L-glutamine, $1 \%$ nonessential amino acid, $0 \cdot 2 \%$ BSA, N2 supplement, B27 supplement (all from Invitrogen), $2 \mu \mathrm{g} / \mathrm{ml}$ heparin, $20 \mathrm{ng} / \mathrm{ml} \mathrm{bFGF}$, and $20 \mathrm{ng} / \mathrm{ml}$ EGF. The cells were treated with $1 \mu \mathrm{M}$ 5-AZA (Sigma) for $24 \mathrm{~h}$. After $24 \mathrm{~h}$ the medium was changed and cells were treated with $100 \mathrm{nM}$ TSA (Sigma) for $24 \mathrm{~h}$. In the second step (induction), the basal medium was changed with induction medium containing DMEM with low glucose ( $1 \mathrm{~g} / \mathrm{l}$; Invitrogen), $1 \times$ insulin-transferin-selenium (ITS; Invitrogen), $2 \mu \mathrm{M}$ all-trans RA (Sigma), and main components. The cells were maintained in induction medium for about 7 days. In the third step (differentiation), the cells were seeded into 6-well plates coated with poly-L-ornithine $\left(15 \mu \mathrm{g} / \mathrm{ml}\right.$; Sigma) at a concentration of $2-5 \times 10^{5}$ cells $/$ well in differentiation medium containing DMEM with high glucose (Invitrogen) and main components for 7 days. In the last step (maturation) the medium was modified from differentiation medium, adding $10 \mathrm{mM}$ nicotinamide (Sigma) without supplement of bFGF and EGF for 7 days. For each step the medium was changed every 2 days.

\section{Quantitative real-time PCR}

Cells were harvested at different steps and total RNA was extracted using RNeasy Minikit (Qiagen), according to the manufacturer's instruction. cDNA was prepared using Superscript reverse transcriptase (Invitrogen). cDNA samples derived from $50 \mathrm{ng}$ of total RNA was analyzed by quantitative reverse transcription-PCR (qRT-PCR) using SYBR green dye with QuantiTect SYBR Green RT-PCR kit (Qiagen). Sequences of PCR primers used are listed in Table 1. PCR was performed with cycles at $95{ }^{\circ} \mathrm{C}$ for $15 \mathrm{~s}, 56-60{ }^{\circ} \mathrm{C}$ for $10 \mathrm{~s}$ (Table 1 ) and $72{ }^{\circ} \mathrm{C}$ for $20 \mathrm{~s}$. Reactions (40 cycles) were carried out with iCycler PCR machine (Bio-Rad) and data analysis was performed with QPCR software (Applied Biosystems, Foster City, CA, USA). Each experiment was performed at least three times. Relative quantitative analysis was performed following $2^{-\Delta \Delta C_{\mathrm{T}}}$. The expression of each gene was normalized to $\beta$-actin gene expression.

Table 1 PCR primer sets

\begin{tabular}{|c|c|c|c|}
\hline & Primer sequences & Annealing $\mathbf{T}\left({ }^{\circ} \mathrm{C}\right) /$ time $(\mathrm{s})$ & References \\
\hline Nestin & $\begin{array}{l}\text { F: } 5^{\prime} \text {-gcggggcggtgcgtgactac-3' } \\
\text { R: } 5^{\prime} \text {-aggcaagggggaagagaaggatgt-3' }\end{array}$ & $58 / 10$ & Zulewski et al. (2001) \\
\hline$P d x 1$ & $\begin{array}{l}\text { F: } 5^{\prime} \text {-atcactggagcagggaagt- } 3^{\prime} \\
\text { R: } 5^{\prime} \text {-gctactacgtttcttatct- } 3^{\prime}\end{array}$ & $56 / 10$ & Zulewski et al. (2001) \\
\hline Ngn3 & $\begin{array}{l}\text { F: } 5^{\prime} \text {-ccgcgtggagtgacctctaa-3' } \\
\text { R: } 5^{\prime} \text {-ggtggaattggaactgagcactt-3' }\end{array}$ & $60 / 10$ & Calderari et al. (2007) \\
\hline CK19 & $\begin{array}{l}\text { F: } 5^{\prime} \text {-acagccagtacttcaagacc- } 3^{\prime} \\
\text { R: 5'-ctgtgtcagcacgcacgtta- } 3^{\prime}\end{array}$ & $56 / 10$ & Zulewski et al. (2001) \\
\hline Insulin & $\begin{array}{l}\text { F: } 5^{\prime} \text {-tcttctacacacccatgtccc- } 3^{\prime} \\
\text { R: } 5^{\prime} \text {-cacctagtcacgacgtgg- } 3^{\prime}\end{array}$ & $55 / 10$ & Jonas et al. (1999)/J00747-8 \\
\hline Glucagon & $\begin{array}{l}\text { F: } 5^{\prime} \text {-acctagactcccgccgtg- } 3^{\prime} \\
\text { R: } 5^{\prime} \text {-cttgaacccgcgtctgta-3' }\end{array}$ & $55 / 10$ & Jonas et al. (1999)/K02808 \\
\hline PP & $\begin{array}{l}\text { F: } 5^{\prime} \text {-cgcatactactgcctctccc- } 3^{\prime} \\
\text { R: } 5^{\prime} \text {-cagcagcgcagggcatcaaa- } 3^{\prime}\end{array}$ & $60 / 10$ & Choi et al. (2005) \\
\hline Som & $\begin{array}{l}\text { F: } 5^{\prime} \text {-ctgcatcgtcctggctttgg-3 } \\
\text { R: } 5^{\prime} \text {-tgcagccagctttgcgttcc-3' }\end{array}$ & $55 / 10$ & Choi et al. (2005) \\
\hline Glut2 & $\begin{array}{l}\mathrm{F}: 5^{\prime} \text {-ggatctgctcacatagtcac- } 3^{\prime} \\
\mathrm{R}: 5^{\prime} \text {-ccaagtaggatgtgccagta-3 }\end{array}$ & $60 / 10$ & Choi et al. (2005) \\
\hline$\beta$-actin & $\begin{array}{l}\text { F: } 5^{\prime} \text {-acctgacagactacctcatg-3' } \\
\text { R: } 5^{\prime} \text {-atcgtactcctgcttgctga-3' }\end{array}$ & $58 / 10$ & Choi et al. (2005) \\
\hline
\end{tabular}

PP, pancreatic polypeptide; Som, somatostatin; Glut2, glucose transporter 2. 


\section{Immunocytochemistry}

Spheroids were fixed in 4\% paraformaldehyde in phosphate buffer for $10 \mathrm{~min}$. Blocking was carried out for $30 \mathrm{~min}$ using $10 \%$ FCS diluted in PBS at room temperature. The cells were then incubated with primary antibodies in solution of $3 \%$ of FCS in PBS for an hour at room temperature. Antibody dilutions were as follows: mouse monoclonal anti-nestin (MAB353) (1:100; Millipore Corporate, Bellerica, MA, USA), goat anti-PDX1, rabbit anti-PAX6, rabbit anti-CK19, rabbit anti-insulin, goat anti-glucagon, and rabbit anti-amylase (All 1:50, from Santa Cruz Biotechnology, Santa Cruz, CA, USA). Afterwards, the cells were washed with PBS for $5 \mathrm{~min}$ for three times. Secondary antibodies were FITC or Texas red conjugated anti-mouse, anti-goat and anti-rabbit (Vector Laboratories, Inc., Burlingame, CA, USA) and were diluted 1:500 in PBS containing 3\% of FCS. Cells were incubated in this solution for $45 \mathrm{~min}$ at room temperature, followed by washes in PBS for $5 \mathrm{~min}$ for three times. Matched exposure of control sample was stained using non-immune calf serum in place of the primary antibodies. Nuclear DNA was stained with 4',6-diamidino-2-phenylindole (Vector Lab). Images were captured by digital camera connected with fluorescent microscope (Model Upright Zeiss, Jena, Germany). Scanning confocal images were obtained by a confocal microscope (Leica Microsystems SP5, Mannheim, Germany).

\section{Dithizone staining}

Dithizone (DTZ, Sigma), which stains zinc-containing cells bright red, was used to quickly assess the presence of insulinproducing cells. The staining protocol was followed from the study by Shiroi et al. (2002). DTZ stock solution was prepared by solving $50 \mathrm{mg}$ of DTZ in $5 \mathrm{ml}$ of dimethyl sulfoxide (Sigma), sterile-filtering through a $0 \cdot 22 \mu \mathrm{m}$ nylon filter, and stored at $-20{ }^{\circ} \mathrm{C}$. The working solution was prepared $(\mathrm{pH}$ $7 \cdot 8$ ) by diluting the stock solution 1:100 in culture medium. For each dish, $2 \mathrm{ml}$ of DTZ solution was added and incubated for $30 \mathrm{~min}$ at $37^{\circ} \mathrm{C}$. After washing the cells three times in PBS, the differentiated islet-like clusters were examined under phase contrast inverse microscope.
Step 2
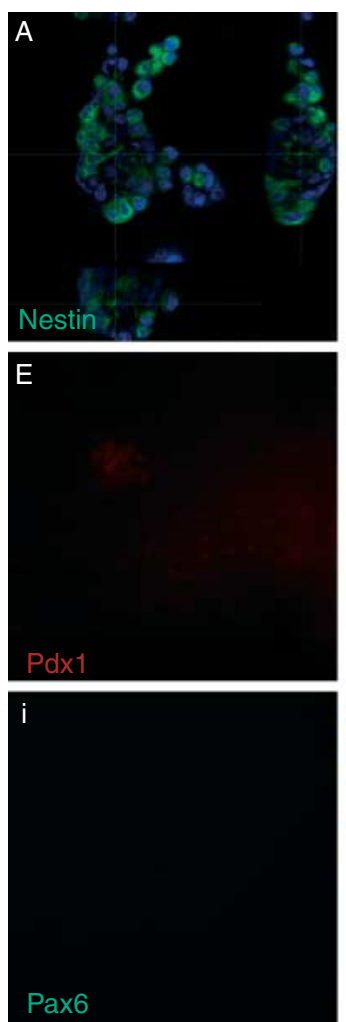
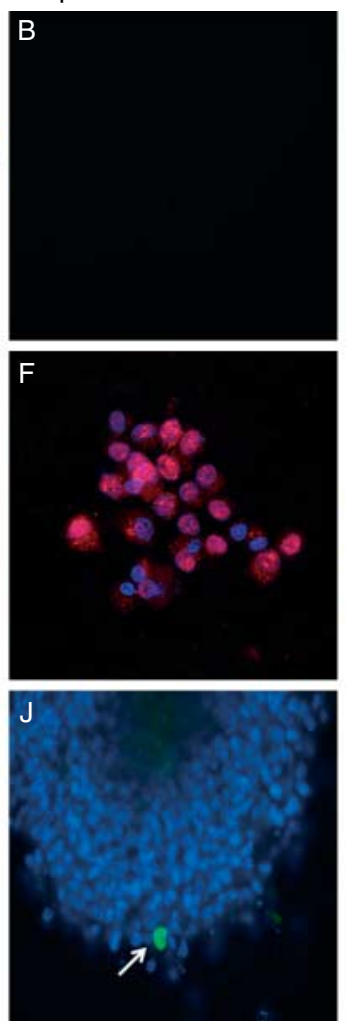

Step 3
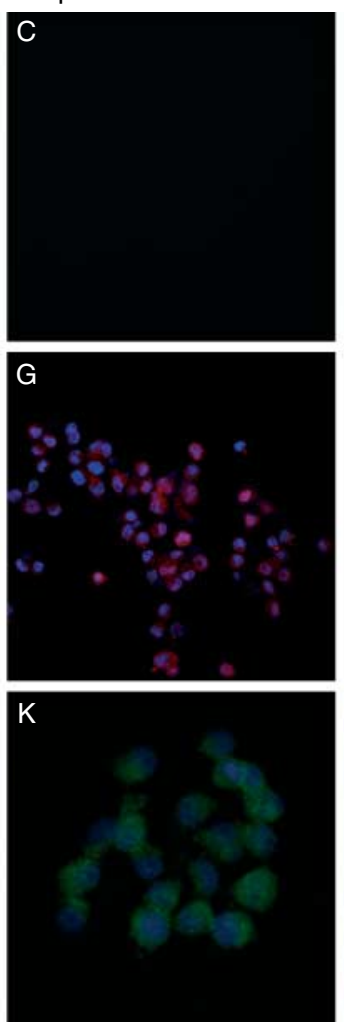

Step 4
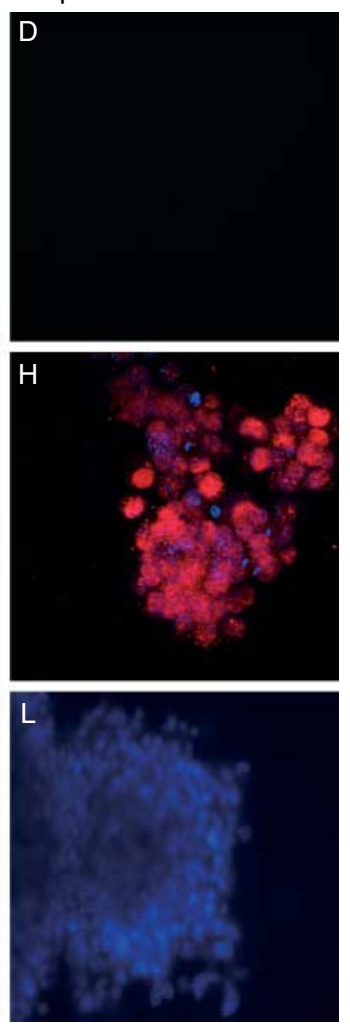

Figure 2 Expression of nestin and pancreatic transcription factors during in vitro n-BMSC differentiation. (A-D) Immunofluorescence staining for nestin was positive $(A)$ in the beginning and negative in the following differentiation step. (E-H) Immunofluorescence for PDX1 was negative in the beginning (A) and positive in the three following steps. (I-N) Immunofluorescence staining for PAX6 was negative in the beginning (A); positive in only few cells by step $2(\mathrm{~L})$, and in many cells by step $3(\mathrm{M})$; negative again in the last step (N). Nuclei were counterstained with DAPI. Confocal microscopy, original magnification $\times 63(\mathrm{~A}, \mathrm{~F}, \mathrm{G}$, and H); Fluorescent microscopy $\times 40(\mathrm{M})$ and $\times 20(\mathrm{~L}$ and $\mathrm{N})$. 
A

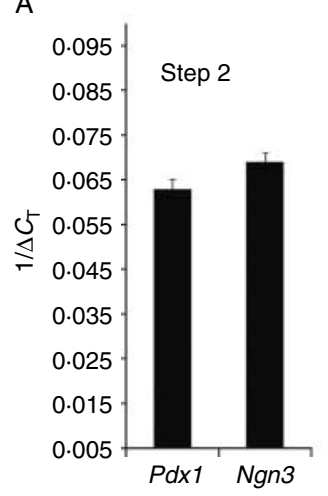

B

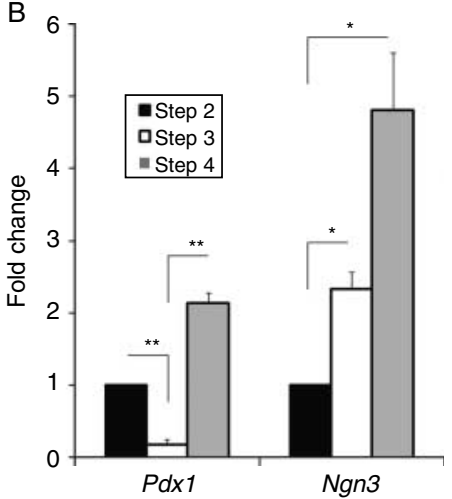

Figure 3 Quantitative reverse transcription-PCR analysis of n-BMSC for $P d x 1$ and $N g n 3(\mathrm{~A}): P d x 1$ and Ngn3 genes were not expressed in the beginning of pancreatic differentiation in vitro but were induced during step 2 of the differentiation protocol. $\Delta C_{\mathrm{T}}$ presents the difference of the cycle threshold between the assayed gene and the normalizing gene. (B) Variation of gene expression during in vitro differentiation. Values are fold change \pm s.D. $(n=3)$. ${ }^{*} P<0 \cdot 05 ; * * P<0 \cdot 01$.

\section{Insulin assay}

For each determination, about 100 spheroids of similar size were randomly handpicked at stage 4 ( 3 weeks after starting the pancreatic differentiation) and incubated in DMEM with low glucose $(1 \mathrm{~g} / \mathrm{l})$ without serum overnight. For insulin secretion assays spheroids were preincubated for $1 \mathrm{~h}$ in Krebs-Ringer/bicarbonate buffer (KRB: $120 \mathrm{mM} \mathrm{NaCl}$, $5 \mathrm{mM} \mathrm{KCl}, 2.5 \mathrm{mM} \mathrm{CaCl}_{2}, 1 \cdot 1 \mathrm{mM} \mathrm{MgCl}$, and $25 \mathrm{mM}$ $\mathrm{NaHCO}_{3}$ ) at $37^{\circ} \mathrm{C}$ or on ice (for control experiments) in $5 \% \mathrm{CO}_{2}$ atmosphere, followed by incubation for an additional hour in KRB containing $0.5 \mathrm{mM} 1$-isobutyl-3methylxanthine and glucose at different concentrations (5, 10 , and $20 \mathrm{mM}$ ). The buffer was collected and frozen at $-70{ }^{\circ} \mathrm{C}$ until assay for insulin content. The amount of insulin released was determined by ultrasensitive rat insulin ELISA (Linco Research, Billerica, MA, USA) according to the manufacturer's protocol. Values showed the mean of three replicates \pm s.D.

\section{Statistical analysis}

Results are shown as mean \pm s.D. Student $t$-test was used to compare between two groups. One-way ANOVA was used to compare among three groups. In all statistical analyses, a $P$ value of $<0.05$ was judged statistically significant.

\section{Results}

To drive differentiation of bone marrow stem cells expressing nestin towards pancreatic lineages, we developed a culture procedure comprising four steps (Fig. 1). In the first step the cells were exposed to 5-AZA for $24 \mathrm{~h}$ and TSA for another $24 \mathrm{~h}$. The dose of 5-AZA used in our study has been

successfully used by Lefebvre et al. (2009) to induce NGN3 expression and endocrine differentiation into the PANC-1 human ductal cell line. We determined the optimal concentrations of TSA by testing cell survival, growth and death with increasing doses from $10 \mathrm{nM}$ to $1 \mathrm{mM}$. Concentrations of more than $100 \mathrm{nM}$ for TSA showed an increased cell death and reduced differentiation capability (data not shown). We rationalized that chromatin remodeling is the first step to induce nestin-positive cells because of putative cell lineage differences and specification, and hypothesized that the increased 'susceptibility' of chromatin by serial epigenetic modifications will enhance the induction and further direct differentiation toward the pancreatic phenotype (Fig. 1). After exposure to TSA, the cells were cultured for 7 days in a serum-free medium containing ITS and RA (Fig. 1C, induction). The concentration of RA adopted in our study was previously optimized in embryonic stem cell differentiation model (Cai et al. 2009). Recently, the role of RA in pancreatic development and early endocrine lineage determination has been shown (Ostrom et al. 2008). In addition, RA has been used for both mouse and human embryonic stem cells to induce differentiation into pancreatic cell lineage (Micallef et al. 2005, Johannesson et al. 2009). At this time point we were able to highly induce the expression of a pancreatic master gene (pancreas duodenum homeobox-1, PDX1), together with other genes important in the early pancreatic development (PAX6 and NGN3). Many cells were positive for PDX1 as assayed by immunohistochemistry (Fig. 2F). Subsequently, the PDX1-positive cell population dramatically decreased after 7 days during the third step (differentiation; Fig. 2G) but increased again and became prominent in the fourth step (maturation; Fig. $2 \mathrm{H}$ ). This fluctuation of PDX1-positive cell population by immunohistochemistry also appeared in the qRT-PCR analysis in sequential manner (Fig. 3B). $P d x 1$ gene expression was initiated within 7 days during the second step culture

Table 2 Expression of pancreatic transcription factors and islet hormone transcripts at different time points during in vitro differentiation

\begin{tabular}{|c|c|c|c|c|}
\hline & Time 0 & $\begin{array}{l}\text { Step } 2 \\
\text { (day 9) }\end{array}$ & $\begin{array}{l}\text { Step } 3 \\
\text { (day 16) }\end{array}$ & $\begin{array}{l}\text { Step } 4 \\
\text { (day 23) }\end{array}$ \\
\hline Nestin & $26 \pm 1$ & - & - & - \\
\hline$P d x 1$ & - & $29 \pm 0.5$ & $32 \pm 1$ & $27 \pm 1$ \\
\hline Ngn3 & - & $28 \pm 0 \cdot 2$ & $27 \pm 0 \cdot 2$ & $26 \pm 0 \cdot 1$ \\
\hline Insulin & - & - & $27 \pm 0 \cdot 2$ & $23 \pm 1$ \\
\hline Glucagon & - & - & $29 \pm 0 \cdot 1$ & $26 \pm 0 \cdot 2$ \\
\hline Glut2 & - & - & $29 \pm 0 \cdot 1$ & $27 \pm 0.5$ \\
\hline Ck19 & - & - & $25 \pm 0 \cdot 1$ & $23 \pm 0 \cdot 1$ \\
\hline Amylase & - & - & - & - \\
\hline Somatostatin & - & - & - & - \\
\hline PP & - & - & - & - \\
\hline
\end{tabular}

RNA from n-BMSC was extracted at different time points during in vitro differentiation and analyzed by quantitative reverse transcription-PCR for transcripts encoding pancreatic transcription factors and the four islet hormones. Values represent cycle threshold \pm s.D. PP, pancreatic polypeptide. 
(induction), then downregulated several fold but was detectable $\sim 2$ weeks later during the third step, and upregulated again 3 weeks later during the maturation step. Ngn3 transcript was induced at day 7 and progressively increased two- to fivefold at day 14 (step 3) and day 21 (step 4) respectively (Fig. 3). Only a few cells were positive for PAX6 at day 9 , as confirmed by immunohistochemistry (Fig. 2) and the number of positive cells strongly increased during step 3, but was not detectable at step 4 . Surprisingly, these results were consistent with the physiological expression of PDX1, $P A X 6$, and NGN3 genes during in vivo pancreas development. In contrast, nestin expression was high in the beginning of the differentiation and dramatically decreased to an undetectable level during the second stage of conditioning. This was confirmed by both immunohistochemistry and (Fig. 2A-D) and qRT-PCR (Table 2). Morphologically, the cells stayed aggregated in spheroid structure.

In the third stage of conditioning we used poly-Lornithine-coated dishes with a medium containing high glucose with both bFGF and EGF. In such an environment, the cells underwent further differentiation into a pancreatic phenotype. At about 2 weeks of the differentiation process, corresponding to the maximized expression of PAX6, increased expression of NGN3 and downregulation of PDX1, endocrine markers for a more mature phenotype started to appear as confirmed by qRT-PCR: insulin, glucagon, and glucose transporter 2 (Glut2; Table 2). The expression of Ck19, a ductal marker, was also induced. At this stage immunohistochemistry was negative for the same markers (Fig. 4).

In the last step, we tried to further push the differentiation toward a more mature phenotype. For this reason we used nicotinamide for about 7 days. At day 21 from the beginning of the in vitro differentiation, we observed a mixed population of cells expressing endocrine and ductal phenotypes. Immunofluorescent staining was markedly positive for insulin and CK19 (Fig. 4). These cells also positively stained with the zinc chelator, DTZ, indicating the presence of intracellular proinsulin, as has been previously observed for 'pseudoislets' in culture (Kuo et al. 1992). Only a small number of cells were positive for glucagon with immunofluorescent staining (data not shown). Insulin, CK19, and glucagon transcripts were also consistently upregulated (seven- to eightfold, five- to sixfold and two- to threefold, respectively; Fig. 5A and B). No amylase was detected on immunohistochemistry (data not shown) and RNA levels (Table 2), indicating the absence of a pancreatic exocrine phenotype. In our culture condition we also failed to detect somatostatin and pancreatic polypeptide-positive cells (Table 2).

To evaluate the functionality of differentiated cells, we tested for glucose-induced insulin secretion in vitro. At the end of the last differentiation stage, the cell aggregate (spheroids) not only produced insulin, but also displayed a glucoseresponsive secretion of the hormone. Insulin secretion was dose-dependent after incubation for $1 \mathrm{~h}$ with glucose $(5,10$, and $20 \mathrm{mM}$; Fig. 5C). Spheroids incubated on ice under
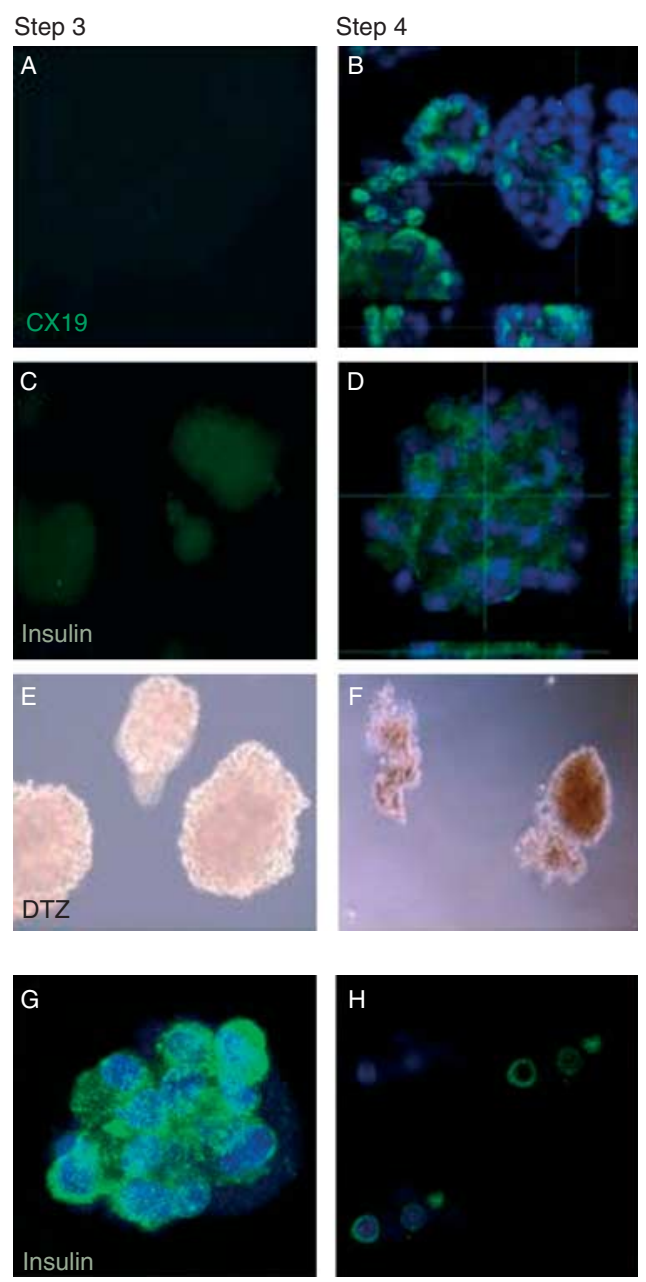

Figure 4 Differentiation of $n-B M S C$ in a mature pancreatic phenotype. Immunofluorescence staining for CK19 (A and B) and for insulin (C and D) was negative until the third differentiation step and became positive in the last step (B and $D)$. Dithizone staining for proinsulin ( $E$ and $F$ ) was also positive in the last differentiation step. Nuclei were counterstained with DAPI. Images of insulin staining visualized under confocal microscope (D-G) with detail of single-cell sectioning $(\mathrm{H})$ showing the insulin granular cytoplasmatic pattern. Confocal microscopy, original magnification $\times 63$ $(B, D, G$, and $H)$; phase contrast microscopy, original magnification $\times 20(\mathrm{E}$ and $\mathrm{F})$

the same condition did not show glucose-responsive insulin secretion. The average insulin secretion on ice with glucose 5,10 , and $20 \mathrm{mM}$ was $0 \cdot 85 \pm 0 \cdot 32,1 \cdot 5 \pm 0 \cdot 41$, and $1 \cdot 8$ $\pm 0.5 \mathrm{ng} / 100$ spheroids per hour respectively. This is consistent with inhibition of glucose-induced insulin release by cooling (Atwater et al. 1984). These findings demonstrate de novo synthesis and processing of insulin and physiologically regulated secretion. Moreover the cells expressed a functional element, Glut2 (Fig. 5A and B) that allows the rapid entry of glucose into the cells. This confirmed the capability of our differentiated cells to respond to glucose stimulation. 

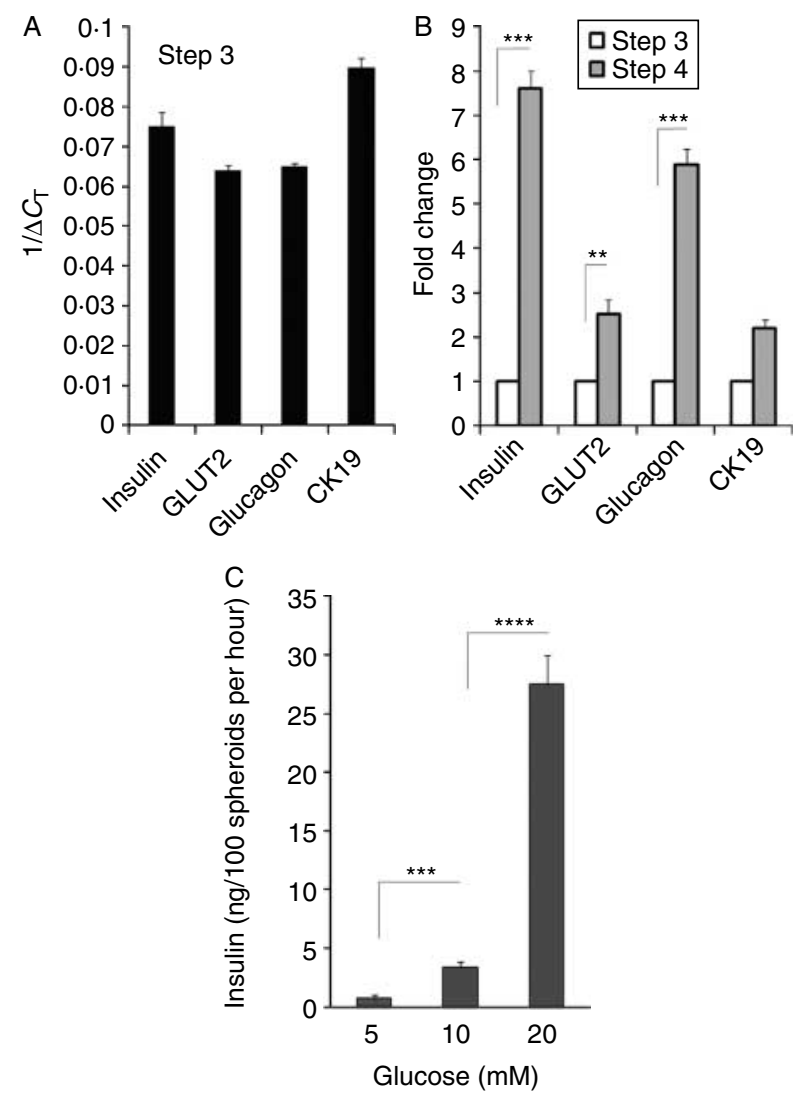

Figure 5 Quantitative reverse transcription-PCR analysis of n-BMSC. (A) Gene not expressed in the beginning of pancreatic differentiation in vitro and induced during step 3 of the differentiation protocol. $\Delta C_{\mathrm{T}}$ represents the difference between the cycle threshold of the assayed gene and that of the normalizing gene. (B) Variation of gene expression during in vitro differentiation. (C) Insulin production in response to glucose concentration: $\mathrm{n}$-BMSCs were incubated in a buffer containing the indicating concentration of glucose. Values are fold change \pm s.D. $(n=3)$. ${ }^{* *} P<0 \cdot 01 ;{ }^{* * *} P<0 \cdot 005 ;{ }^{* * * *} P<0 \cdot 0001$.

\section{Discussion}

Promising results of pancreatic islet transplantation to treat diabetes mellitus, combined with severe shortage of donor pancreata, have spurred efforts to generate insulin-secreting $\beta$-cells from various progenitor populations. In this study, we report a novel culture system in order to obtain insulinproducing cells derived from nestin-positive bone marrow cells in rats (n-BMSC). Our procedure successfully induced n-BMSC to express lineage-specific transcription factor, in particular Pdx1, which has been shown to drive pancreatic differentiation.

We pretreated the cells with 5-AZA to inhibit DNA methylation, which has been recognized in important differentiation processes, such as osteoblast (Vaes et al. 2009), cardiomycyte (Tomita et al. 1999) and more recently pancreatic endocrine differentiation (Lefebvre et al. 2009).
We sequentially treated the cells with TSA based on the hypothesis that chromatin remodeling will enhance the induction and further differentiation toward pancreatic lineage. Acetylation or deacetylation of histone terminal domains can regulate gene expressions. Histone acetyltransferases and HDACs can loosen or compact chromatin structures and regulate cell proliferation and differentiation in various tissues (Zhang et al. 2002, Chang et al. 2004). As the acetylation status of nucleosomal histone modulates chromatin structure and epigenetically regulates gene expression, an inhibitor of both classes I and II HDACs such as TSA may be used to loosen the chromatin structure and more easily permit differentiation through epigenetic manipulation. Moreover, a recent study from Haumaitre et al. (2008) showed that HDAC inhibitors can modify the timing and the determination of pancreatic cell fate with inhibition of exocrine and enhancement of ductal and endocrine differentiation. In our experiment, after exposure to 5-AZA and TSA, the cells lost nestin expression and after being cultured in a medium containing ITS and RA, they also turned on expression of mRNA encoding transcription factors such as $P d x 1, N g N 3$ and $P a x 6$, well known to play important roles in the developmental program leading to the formation of pancreatic islets (Jensen 2004). Moreover, the expression of these transcription factors followed the timing consistent with the normal mammalian pancreatic development. PDX1 was expressed in the second step after exposure to RA and ITS medium and subsequently expression of both PAX6 and NGN3 were activated. In the last step, a more mature phenotype of ductal and endocrine pancreatic cells appeared. These cells lost the expression of PAX6, and upregulated PDX1, insulin, glucagon, GLUT2 and CK19.

Another crucial step in our differentiation protocol is the use of RA to induce differentiation of n-BMSC towards a pancreatic phenotype. In our experiment it was extremely important to time the exposure to RA, right after the cell treatment with TSA. RA has been shown to control multiple steps in the motor neuron differentiation in the ventral spinal cord (Novitch et al. 2003). In an elegant experiment, Ostrom et al. (2008) showed that RA is present in the developing mouse and human pancreas and is required for pancreas development. Moreover, all-trans RA has been widely used to promote generation of PDX1-positive pancreatic progenitor cells from mouse embryonic stem cells (Micallef et al. 2005, Shi et al. 2005) and to induce pancreatic differentiation in human embryonic stem cells (D'Amour et al. 2006, Johannesson et al. 2009). In our experiment, consistent with the previous observations, we showed that RA induces expression of PDX1.

In the last step both ductal and endocrine phenotypes were present and this is probably because the activation of $P d x 1$ in the second step of our protocol, subsequently activated both the endocrine and the non-endocrine pathways. $P d x 1$ is well known for controlling early whole pancreas development. 
Our starting hypothesis was that a selected stem cell population from rat whole bone marrow highly expressing nestin could be a potential multipotent precursor stem cell able to differentiate to pancreatic cell lineage. Our hypothesis was based on the evidence that nestin is a neuroepithelial marker transiently expressed in early stages in many tissues, including pancreas, and that nestin-positive cells from pancreas can be differentiated in culture into endocrine, exocrine, and ductal cells (Zulewski et al. 2001).

We demonstrated that epigenetic manipulation of n-BMSC, following a specific multistep protocol, can induce expression of transcription factors involved in the early pancreatic and endocrine specification in a step-wise fashion whose timing was consistent with normal pancreas development. Differentiation into a more mature phenotype, including ductal and insulin-producing cells was efficiently induced. It remains to be shown how long these cells remain in this differentiated state both in vitro and in vivo. In conclusion, we propose a novel cellular system that can address these unmet needs, both for cell therapy and for mechanistic studies and drug discovery in the field of pancreatic islet neogenesis.

\section{Declaration of interest}

The authors declare that there is no conflict of interest that could be perceived as prejudicing the impartiality of the research reported.

\section{Funding}

This work was founded in part by NIH grants R01NS048959 and R56NS04895 (to J S Y) and by Endocrine Fellow Foundation (to A M).

\section{Acknowledgements}

We thank Kolja Wawrowski (Cedars-Sinai Medical Center) for assistance with confocal microscopy.

\section{References}

Alpert S, Hanahan D \& Teitelman G 1988 Hybrid insulin genes reveal a developmental lineage for pancreatic endocrine cells and imply a relationship with neurons. Cell 53 295-308. (doi:10.1016/0092-8674(88) 90391-1)

Atwater I, Goncalves A, Herchuelz A, Lebrun P, Malaisse WJ, Rojas E \& Scott A 1984 Cooling dissociates glucose-induced insulin release from electrical activity and cation fluxes in rodent pancreatic islets. Journal of Physiology $\mathbf{3 4 8}$ 615-627.

Bonner-Weir S 2000 Life and death of the pancreatic beta cells. Trends in Endocrinology and Metabolism 11 375-378. (doi:10.1016/S1043-2760(00) 00305-2)

Bonner-Weir S $2001 \beta$-Cell turnover: its assessment and implications. Diabetes 50 (Suppl 1) S20-S24. (doi:10.2337/diabetes.50.2007.S20)

Bouwens L \& Kloppel G 1996 Islet cell neogenesis in the pancreas. Virchows Archiv 427 553-560. (doi:10.1007/BF00202885)
Cai J, Yu C, Liu Y, Chen S, Guo Y, Yong J, Lu W, Ding M \& Deng H 2009 Generation of homogeneous PDX1 + pancreatic progenitors from human ES cell-derived endoderm cells. Journal of Molecular Cell Biology 2 50-60. (doi:10.1093/jmcb/mjp037)

Calderari S, Gangnerau MN, Thibault M, Meile MJ, Kassis N, Alvarez C, Portha B \& Serradas P 2007 Defective IGF2 and IGF1R protein production in embryonic pancreas precedes beta cell mass anomaly in the GotoKakizaki rat model of type 2 diabetes. Diabetologia 50 1463-1471. (doi:10. 1007/s00125-007-0676-2)

Chang S, McKinsey TA, Zhang CL, Richardson JA, Hill JA \& Olson EN 2004 Histone deacetylases 5 and 9 govern responsiveness of the heart to a subset of stress signals and play redundant roles in heart development. Molecular and Cellular Biology 24 8467-8476. (doi:10.1128/MCB.24.19. 8467-8476.2004)

Choi KS, Shin JS, Lee JJ, Kim YS, Kim SB \& Kim CW 2005 In vitro transdifferentiation of rat mesenchymal cells into insulin-producing cells by rat pancreatic extract. Biochemical and Biophysical Research Communications 330 1299-1305. (doi:10.1016/j.bbrc.2005.03.111)

D'Amour KA, Bang AG, Eliazer S, Kelly OG, Agulnick AD, Smart NG, Moorman MA, Kroon E, Carpenter MK \& Baetge EE 2006 Production of pancreatic hormone-expressing endocrine cells from human embryonic stem cells. Nature Biotechnology 24 1392-1401. (doi:10.1038/nbt1259)

Dor Y, Brown J, Martinez OI \& Melton DA 2004 Adult pancreatic beta-cells are formed by self-duplication rather than stem-cell differentiation. Nature 429 41-46. (doi:10.1038/nature02520)

Gao X, Song L, Shen K, Wang H, Niu W \& Qin X 2008 Transplantation of bone marrow derived cells promotes pancreatic islet repair in diabetic mice. Biochemical and Biophysical Research Communications 371 132-137. (doi:10. 1016/j.bbrc.2008.04.033)

Hasegawa Y, Ogihara T, Yamada T, Ishigaki Y, Imai J, Uno K, Gao J, Kaneko K, Ishihara $\mathrm{H}$, Sasano $\mathrm{H}$ et al. 2007 Bone marrow (BM) transplantation promotes beta-cell regeneration after acute injury through $\mathrm{BM}$ cell mobilization. Endocrinology 148 2006-2015. (doi:10.1210/en.2006-1351)

Haumaitre C, Lenoir O \& Scharfmann R 2008 Histone deacetylase inhibitors modify pancreatic cell fate determination and amplify endocrine progenitors. Molecular and Cellular Biology 28 6373-6383. (doi:10.1128/MCB.00413-08)

Hunziker E \& Stein M 2000 Nestin-expressing cells in the pancreatic islets of Langerhans. Biochemical and Biophysical Research Communications 271 116-119. (doi:10.1006/bbrc.2000.2611)

Ianus A, Holz GG, Theise ND \& Hussain MA 2003 In vivo derivation of glucose-competent pancreatic endocrine cells from bone marrow without evidence of cell fusion. Journal of Clinical Investigation 111 843-850.

Jensen J 2004 Gene regulatory factors in pancreatic development. Developmental Dynamics 229 176-200. (doi:10.1002/dvdy.10460)

Johannesson M, Stahlberg A, Ameri J, Sand FW, Norrman K \& Semb H 2009 FGF4 and retinoic acid direct differentiation of hESCs into PDX1-expressing foregut endoderm in a time- and concentrationdependent manner. PLoS ONE 4 e4794. (doi:10.1371/journal.pone. 0004794)

Jonas JC, Sharma A, Hasenkamp W, Ilkova H, Patanè G, Laybutt R, BonnerWeir S \& Weir GC 1999 Chronic hyperglycemia triggers loss of pancreatic beta cell differentiation in an animal model of diabetes. Journal of Biological Chemistry 274 14112-14121. (doi:10.1074/jbc.274.20.14112)

Kabos P, Ehtesham M, Kabosova A, Black KL \& Yu JS 2002 Generation of neural progenitor cells from whole adult bone marrow. Experimental Neurology 178 288-293. (doi:10.1006/exnr.2002.8039)

Kim SY, Lee SH, Kim BM, Kim EH, Min BH, Bendayan M \& Park IS 2004 Activation of nestin-positive duct stem (NPDS) cells in pancreas upon neogenic motivation and possible cytodifferentiation into insulin-secreting cells from NPDS cells. Developmental Dynamics 230 1-11. (doi:10.1002/ dvdy.20012)

Kim SY, Lee S, Hong SW, Min BH, Lee KU, Bendayan M \& Park IS 2010 Nestin action during insulin-secreting cell differentiation. Journal of Histochemistry and Cytochemistry 58 567-576. (doi:10.1369/jhc.2010.955682)

Kuo CY, Herrod HG \& Burghen GA 1992 Formation of pseudoislets from human pancreatic cultures. Pancreas 7 320-325. (doi:10.1097/00006676199205000-00008) 
Lakey JR, Mirbolooki M \& Shapiro AM 2006 Current status of clinical islet cell transplantation. Methods in Molecular Biology 333 47-104. (doi:10.1385/ 1-59745-049-9:47)

Lefebvre B, Belaich S, Longue J, Vandewalle B, Oberholzer J, Gmyr V, Pattou F \& Kerr-Conte J 2009 5'-AZA induces Ngn3 expression and endocrine differentiation in the PANC-1 human ductal cell line. Biochemical and Biophysical Research Communications 391 305-309. (doi:10.1016/j.bbrc. 2009.11.054)

Lendahl U, Zimmerman LB \& McKay RD 1990 CNS stem cells express a new class of intermediate filament protein. Cell 60 585-595. (doi:10.1016/ 0092-8674(90)90662-X)

Madsen OD, Jensen J, Petersen HV, Pedersen EE, Oster A, Andersen FG, Jorgensen MC, Jensen PB, Larsson LI \& Serup P 1997 Transcription factors contributing to the pancreatic beta-cell phenotype. Hormone and Metabolic Research 29 265-270. (doi:10.1055/s-2007-979035)

Matsuoka M, Osada T, Yoshida-Matsuoka J, Ikai A, Ichikawa M, Norita M \& Costanzo RM 2002 A comparative immunocytochemical study of development and regeneration of chemosensory neurons in the rat vomeronasal system. Brain Research 946 52-63. (doi:10.1016/s00068993(02)02823-8)

Micallef SJ, Janes ME, Knezevic K, Davis RP, Elefanty AG \& Stanley EG 2005 Retinoic acid induces Pdx1-positive endoderm in differentiating mouse embryonic stem cells. Diabetes 54 301-305. (doi:10.2337/diabetes.54.2.301)

Morshead CM, Reynolds BA, Craig CG, McBurney MW, Staines WA, Morassutti D, Weiss S \& van der Kooy D 1994 Neural stem cells in the adult mammalian forebrain: a relatively quiescent subpopulation of subependymal cells. Neuron 13 1071-1082. (doi:10.1016/0896-6273(94)90046-9)

Novitch BG, Wichterle H, Jessell TM \& Sockanathan S 2003 A requirement for retinoic acid-mediated transcriptional activation in ventral neural patterning and motor neuron specification. Neuron 40 81-95. (doi:10. 1016/j.neuron.2003.08.006)

Ostrom M, Loffler KA, Edfalk S, Selander L, Dahl U, Ricordi C, Jeon J, Correa-Medina M, Diez J \& Edlund H 2008 Retinoic acid promotes the generation of pancreatic endocrine progenitor cells and their further differentiation into beta-cells. PLoS ONE 3 e2841. (doi:10.1371/journal. pone.0002841)

Reynolds BA \& Weiss S 1996 Clonal and population analyses demonstrate that an EGF-responsive mammalian embryonic CNS precursor is a stem cell. Developmental Biology 175 1-13. (doi:10.1006/dbio.1996.0090)

Sander M \& German MS 1997 The beta cell transcription factors and development of the pancreas. Journal of Molecular Medicine 75 327-340. (doi:10.1007/s001090050118)

Shapiro AM, Ricordi C, Hering BJ, Auchincloss H, Lindblad R, Robertson RP, Secchi A, Brendel MD, Berney T, Brennan DC et al. 2006 International trial of the Edmonton protocol for islet transplantation. New England Journal of Medicine 355 1318-1330. (doi:10.1056/NEJMoa061267)

Shi Y, Hou L, Tang F, Jiang W, Wang P, Ding M \& Deng H 2005 Inducing embryonic stem cells to differentiate into pancreatic beta cells by a novel three-step approach with activin A and all-trans retinoic acid. Stem Cells 23 656-662. (doi:10.1634/stemcells.2004-0241)
Shiroi A, Yoshikawa M, Yokota H, Fukui H, Ishizaka S, Tatsumi K \& Takahashi Y 2002 Identification of insulin-producing cells derived from embryonic stem cells by zinc-chelating dithizone. Stem Cells 20 284-292. (doi:10.1634/stemcells.20-4-284)

Talmor M, Mirza A, Turley S, Mellman I, Hoffman LA \& Steinman RM 1998 Generation or large numbers of immature and mature dendritic cells from rat bone marrow cultures. European Journal of Immunology 28 811-817. (doi:10.1002/(SICI)1521-4141(199803)28:03 < 811::AID-IMMU811> 3.0.CO;2-S)

Tomita S, Li RK, Weisel RD, Mickle DA, Kim EJ, Sakai T \& Jia ZQ 1999 Autologous transplantation of bone marrow cells improves damaged heart function. Circulation 100 II247-II256.

Vaes BL, Lute C, van der Woning SP, Piek E, Vermeer J, Blom HJ, Mathers JC, Muller M, de Groot LC \& Steegenga WT 2009 Inhibition of methylation decreases osteoblast differentiation via a non-DNA-dependent methylation mechanism. Bone 46 514-523. (doi:10.1016/j.bone.2009.09.033)

Xu J, Lu Y, Ding F, Zhan X, Zhu M \& Wang Z 2007 Reversal of diabetes in mice by intrahepatic injection of bone-derived GFP-murine mesenchymal stem cells infected with the recombinant retrovirus-carrying human insulin gene. World Journal of Surgery 31 1872-1882. (doi:10.1007/s00268-0079168-2)

Yashpal NK, Li J \& Wang R 2004 Characterization of c-Kit and nestin expression during islet cell development in the prenatal and postnatal rat pancreas. Developmental Dynamics 229 813-825. (doi:10.1002/dvdy.10496)

Ye DZ, Tai MH, Linning KD, Szabo C \& Olson LK 2006 MafA expression and insulin promoter activity are induced by nicotinamide and related compounds in INS-1 pancreatic beta-cells. Diabetes 55 742-750. (doi:10.2337/diabetes.55.03.06.db05-0653)

Zeng Z, Yuan X, Liu G, Zeng X, Ng H, Chen H, Jiang T, Akasaki Y, Kessey $\mathrm{K}$, Black KL et al. 2007 Manipulation of proliferation and differentiation of human bone marrow-derived neural stem cells in vitro and in vivo. Journal of Neuroscience Research 85 310-320. (doi:10.1002/jnr.21131)

Zhang CL, McKinsey TA, Chang S, Antos CL, Hill JA \& Olson EN 2002 Class II histone deacetylases act as signal-responsive repressors of cardiac hypertrophy. Cell 110 479-488. (doi:10.1016/S0092-8674(02)00861-9)

Zhao M, Amiel SA, Ajami S, Jiang J, Rela M, Heaton N \& Huang GC 2008 Amelioration of streptozotocin-induced diabetes in mice with cells derived from human marrow stromal cells. PLoS ONE 3 e2666. (doi:10.1371/ journal.pone.0002666)

Zulewski H, Abraham EJ, Gerlach MJ, Daniel PB, Moritz W, Muller B, Vallejo M, Thomas MK \& Habener JF 2001 Multipotential nestin-positive stem cells isolated from adult pancreatic islets differentiate ex vivo into pancreatic endocrine, exocrine, and hepatic phenotypes. Diabetes $\mathbf{5 0}$ 521-533. (doi:10.2337/diabetes.50.3.521)

Received in final form 15 January 2011

Accepted 17 February 2011

Made available online as an Accepted Preprint 17 February 2011 